Chapman University

Chapman University Digital Commons

Philosophy Faculty Articles and Research

Philosophy

7-5-2011

\title{
Assessing Law's Claim to Authority
}

Bas van der Vossen

Follow this and additional works at: https://digitalcommons.chapman.edu/philosophy_articles

Part of the Ethics and Political Philosophy Commons, and the Law and Philosophy Commons 


\section{Assessing Law's Claim to Authority}

\section{Comments}

This is a pre-copy-editing, author-produced PDF of an article accepted for publication in Oxford Journal of Legal Studies, volume 31, in 2011 following peer review. The definitive publisher-authenticated version is available online at https://doi.org/10.1093/ojls/gqr013.

\section{Copyright}

Oxford University Press 


\title{
Assessing Law's Claim to Authority
}

\author{
Bas van der Vossen \\ Philosophy, UNC Greensboro \\ (published in Oxford Journal of Legal Studies)
}

Abstract-The idea that law claims authority (LCA) has recently been forcefully criticized by a number of authors. These authors present a new and intriguing objection, arguing that law cannot be said to claim authority if such a claim is not justified. That is, these authors argue that the view that law does not have authority viciously conflicts with the view that law claims authority. I will call this the normative critique of LCA. In this article, I assess the normative critique of LCA, focusing predominantly on the arguments presented by its most incisive proponent Philip Soper. I defend a twofold conclusion. First, LCA, understood roughly along the lines put forward by Joseph Raz, is part of the most attractive analysis of law. Second, proponents of the normative critique, and in particular Soper, are committed to accepting LCA.

Keywords: law's claim, Soper, positivism, Raz, natural law, authority

\section{Introduction}

Law, it is often said, claims authority. Among other things, the idea that law claims authority (LCA) forms an important part of the attempt by legal positivist theories to capture the normative character of law. Law is different, such positivist theorists argue, from merely coercive institutional ways of influencing social conduct because it claims authority. At the same time, LCA also shows why law is importantly 
different from, say, morality. For legal requirements present themselves as binding in a manner that does not depend directly upon their content. ${ }^{1}$

LCA has recently been forcefully criticized by a number of authors. These authors present a new and intriguing objection, arguing that law cannot be said to claim authority if such a claim is not justified. That is, these authors argue that the (also popular) view that law does not have authority viciously conflicts with the view that law claims authority. I will call this the normative critique of LCA. The critique can be called 'normative' because it holds that the truth of a normative thesis-that law lacks authority-should move one to abandon the conceptual thesis that law claims such authority. The normative critique has received its most forceful statement in the work of Philip Soper. Soper (rhetorically) asks: 'Why would we continue to accept a concept of law that commits law to claiming authority if, in fact, we do not believe such a claim is defensible as a matter of political theory?'² As a result, the defenders of the normative critique argue that LCA is to be abandoned. ${ }^{3}$

In this article, I wish to assess the normative critique of LCA, focusing predominantly on the arguments presented by Soper. There are at least two reasons for looking in some detail at the normative critique. First, the critique has, at least at first sight, some plausibility-and it definitely has rhetorical force. But it is also not immediately clear how to make sense of it. Part of the purpose of this article is to draw attention to the fact that the normative critique poses, at least on one interpretation,

\footnotetext{
${ }^{1}$ For ease of expression, I here use the phrase 'law claims authority' to be equivalent to 'law claims legitimate authority.' The idea that law claims (legitimate) authority is defended, among others, by Joseph Raz in The Authority of Law (Clarendon Press 1983) chs 2 \& 8, The Morality of Freedom (Clarendon Press 1986) chs 2-4, and 'Authority, Law, and Morality' in Ethics in the Public Domain (OUP 1994); Leslie Green, The Authority of the State (OUP 1988) chs 2, 8-9; Chaim Gans, Philosophical Anarchism and Political Disobedience (CUP 1992) 24-33; Gerald Postema, 'The Normativity of Law' and David Lyons, 'Comment: The Normativity of Law', both in Ruth Gavison (ed), Issues in Contemporary Legal Philosophy (Clarendon Press 1987); William Edmundson, 'Social Meaning, Compliance Conditions, and Law's Claim to Authority' (2002) 15 CJLJ 51.

2 See Philip Soper, The Ethics of Deference (CUP 2002) 52. See also, Philip Soper, 'Law's Normative Claims' in Robert George (ed), The Autonomy of Law (OUP 1996) and Philip Soper, 'Legal Theory and the Claim of Authority' (1989) 18 P\&PA 209.

${ }^{3}$ Other examples of the normative critique are Steven Smith, 'Hart's Onion: The Peeling Away of Legal Authority' (2006) 16 S Cal Interdis LJ 97, esp 99 and 130 and Stefano Bertea, Law's Normative Claim (Hart Publishing 2009). All attempt to strengthen the case for non-positivism by this critique of LCA.
} 
an interesting question about whether law makes a claim to authority. Indeed, I will suggest that, interpreted in this way, the normative critique does have some force against LCA. However, I will also argue that it ultimately fails to show that LCA must be rejected, and in fact provides additional support for that theory. Herein, then, lies the second source of value of the normative critique: it allows us to make the case that law claims authority more forcefully.

More precisely stated, I will defend a twofold conclusion. First LCA, understood roughly along the lines put forward by Joseph Raz, is part of the most attractive analysis of law. And second, proponents of the normative critique such as Soper are, in fact, committed to accepting LCA. The argument will consist of the following steps. Section 2 explains in some more detail about LCA and the normative critique. Three possible interpretations can be given to the normative critique. Sections 3 and 4 will reject two of these as mistaken. Section 5 identifies a third, more interesting interpretation and argues that this version of the critique needs to be taken seriously. Section 6 then assesses how much damage this version of the normative critique inflicts on LCA. Section 7 argues that Soper's alternative theory does worse in light of the normative critique than LCA. Section 8 concludes.

\section{Law's Claim to Authority and the Normative Critique}

Why should we think that law claims authority? The case for the thesis might seem straightforward. Law attempts to regulate the actions of its subjects regarding many different kinds of behaviour. In doing so, legal requirements present themselves as providing subjects with obligations for action that are to be followed regardless of their particular merits. Law rarely allows its subjects to disregard its requirements for reasons it does not recognize as exceptions to its rules. Legal officials act and speak as if these requirements indeed do provide subjects with such obligations and are of a moral kind. Law, in short, seems to claim authority. 
There are grounds for concern however. We should be careful about moving too facilely from the observation that legal requirements present themselves as authoritative to the conclusion that 'the law' claims authority. After all, law consists of more than legal requirements. Nor is the precise relevance of pointing to the language or attitudes adopted by legal officials immediately obvious. How are such facts about persons to fit within a conceptual argument about law? Are they not more properly part of a description of particular legal systems instead $?^{4}$ Finally, some have expressed doubts about whether we can meaningfully speak of law making claims at all. ${ }^{5}$

If it is to be said that law claims authority, then, we must state more precisely the grounds and meaning of that thesis. Doing so will help alleviate these concerns. The thesis depends on two important considerations. The first is the observation above that legal requirements present themselves as authoritative requirements. That is, by their language and logical structure, legal requirements present statements specifying permissible and impermissible acts. These requirements represent the views of some about what people must do in certain circumstances, and are considered binding in a way not directly dependent on their merit. As such, legal requirements purport to pose content-independent obligations ${ }^{6}$ for their subjects. Second, legal officials claim authority when they carry out their professional tasks. That is, they claim that the requirements they issue and uphold impose obligations on people. This claim is one that legal officials implicitly make when exercising their role as legal officials and is due to how their roles and functions are legally defined and to the authoritative structure of the legal requirements they are to uphold and apply. Since legal requirements present themselves as content-independent obligations, officials issuing these requirements present themselves as having, in virtue of their official role, authority.

\footnotetext{
${ }^{4}$ An incisive discussion of the idea that law claims authority, including these criticisms, is Kenneth Einar Himma, 'Law's Claim of Legitimate Authority' in Jules Coleman (ed), The Postscript: Essays on the Postscript to the Concept of Law (OUP 2001).

5 See for example, Kent Greenawalt, 'What Does “the Law" Claim about Trivial and Extremely Broad Legal Norms?' (2005) 50 Am J Juris 305 and Ronald Dworkin, 'Thirty Years On' (2002) 115 Harv L Rev 1655.

${ }^{6}$ For ease of discussion, I will here not distinguish between duties and obligations.
} 
It is often said, among others by Soper, that law's claim to authority is equivalent to the claim that its subjects have a general duty to obey the law. For now we can accept this as basically correct, but it is important to note that strictly speaking LCA is best understood in a slightly different sense. Claiming that all legal requirements are morally obligatory is neither necessary nor sufficient for a claim to authority. It is not sufficient because law's claim might be merely that its requirements track people's independent moral requirements perfectly. In that case, law would simply claim that all of its requirements mirror people's independent obligations, and would thus not claim authority in any meaningful sense. To claim authority is to claim the ability to change the reasons people have for acting. On the other hand, claiming that all legal requirements are morally obligatory is not necessary because law may claim authority while not regarding all of its formal requirements as in fact imposing obligations. ${ }^{7}$ For example, some laws are systematically unenforced. ${ }^{8}$ Others are intentionally formulated in an overbroad manner. The language of such laws includes more ways of acting than were meant to be prohibited by the legislator at the time of drafting the law-and this will be clear to all involved. ${ }^{9}$ Of such laws, again, it seems strange to say that they present themselves as authoritative in any simple sense. ${ }^{10}$

It is more accurate, then, to say that LCA is law's claim that it has the ability to impose contentindependent obligations on subjects. (This is just what it is to possess authority.) Legal requirements present themselves as content-independent obligations, and the people issuing these requirements present themselves, by issuing these requirements in their capacity as legal officials, as having the ability

\footnotetext{
${ }^{7}$ It is obviously true that not all parts of the law claim to impose obligations. Power-conferring rules or laws specifying legal terms form part of the necessary legal background for authoritative requirements, but do not spell out any required actions.

${ }^{8}$ Such as laws against fornication, see Richard Posner and Katharine B Silbaugh, A Guide to America's Sex Laws (University of Chicago Press 1994) ch 7.

${ }^{9}$ See Kent Greenawalt, Conflicts of Law and Morality (OUP 1987) ch 2.

${ }^{10}$ LCA therefore is not vulnerable to the objection that there is no evidence of legal officials in fact making claims about a content-independent duty to obey the law. See for such arguments Himma (n 4) 289 and Soper, The Ethics of Deference (n 2) 82.
} 
to so impact their subjects' practical reasoning. ${ }^{11}$ We might understand LCA, then, as law's claim that it possesses a Hohfeldian power-right vis-à-vis its subjects, meaning it has the ability to make certain actions morally obligatory by requiring them. ${ }^{12}$ As a result, then, law's claim to have the ability to impose content-independent obligations is equivalent to the claim that subjects are obligated to comply with its requirements when law holds them to be so obligated. It is in this way that law claims its subjects can be obligated to do something because the law tells them to do it. Thus we may, somewhat loosely, sum up law's claim to authority as the claim that there is a general content-independent duty to obey the law.

This account of LCA does away with the first two concerns noted above. But what about the third concern: that law cannot make claims? The thesis that law claims authority admittedly involves some degree of personification of the law or of legal systems. However, such talk of attributing certain properties to entities that do not, strictly speaking, possess them (or are incapable of possessing them) is quite common. For example, we say that sports teams are aggressive, physical or lacking composureeven though over time they have been made up of many different individual players. And we do the same with the making of claims. We say that corporations make claims on behalf of their product; we say that political parties claim to strive for a better society; and so on. We make such attributions when doing so is profitable for practical or theoretical considerations. It is in a similar sense that we say that law makes claims. Doing so helps us identify what is part of the function of law (for example, providing an authoritative body of rules). It also helps set apart the pronouncements by persons in their capacity as legal officials from those they utter as private individuals (in the former case the legal official's claims are, in one sense, also law's claims). And these attributions are not based on mere fancy, but on the

\footnotetext{
${ }^{11}$ If all legal systems are ultimately backed by force, law's claim to authority must include the ability to legitimize (permit) the enforcement of its imposed obligations (assuming that obligations are not necessarily enforceable). ${ }^{12}$ See for the argument that political authority is to be conceptualized as a power-right, William Edmundson, 'Political Authority, Moral Powers and the Intrinsic Value of Obedience' (2010) 30 OJLS 179. Another sense in which this account of LCA is different from certain other interpretations is that it holds that, by requiring them, law claims to make certain actions morally obligatory. This is different from those who interpret LCA as the claim that subjects have a separate, free-floating obligation: the obligation to obey the law. I wish to thank an anonymous referee for pressing me to clarify this point.
} 
structure and function of legal requirements. Hence, the kind of attribution of the ability to make claims to law committed by LCA does not involve ascribing to it any mysterious agency that is independent of facts about the law or those who formulate, explicate, uphold and apply it. LCA is not a merely elliptical or figurative claim. Nor does it negate the complexity of law. ${ }^{13}$

Thus, while interpreting LCA as the claim to possess a power is important in various contexts, we can for present purposes (cautiously) follow Soper and interpret LCA in terms of the duty to obey the law. Let us define LCA as follows.

Law's claim to authority (LCA): Law claims that its subjects are obligated to comply with its requirements when it holds them so obligated.

LCA has considerable attractions, and it is part of what Soper sees as the dominant view on the relation between the concepts of law and authority. This consists of a combination of LCA and the denial that law has the authority it claims. That is, many nowadays hold at the same time that law essentially claims its subjects are obligated to obey its requirements and that no such obligation obtains. The normative critique addresses this combination of views. It argues that this combination-according to which there is a gap between what law claims and what law is -is unstable. If successful, the normative critique would show that LCA fails to capture the normative nature of law.

The main motivation for the critique, as Soper puts it, is the thought that, the distinction between facts and values notwithstanding, a more complex relation obtains between moral inquiries and descriptive or conceptual inquiries about the law than is ordinarily supposed. That is, in addition to the familiar view that facts about the world can limit and influence the conclusions of our moral

\footnotetext{
${ }^{13}$ This account draws on and further develops arguments in Raz, The Authority of Law (n 1) ch 2, Raz, 'Authority, Law, and Morality' (n 1) 199-201, 215-16, and John Gardner, 'How Law Claims, What Law Claims' (2008) Oxford Legal Studies Research Paper No 44/2008 <http://ssrn.com/abstract=1299017> accessed 22 June 2010, forthcoming in Matthias Klatt (ed), Institutional Reason: The Jurisprudence of Robert Alexy (OUP). For purposes of the argument below, there is here no important conflict with Soper's view of how law makes claims. See Soper, The Ethics of Deference (n 2) 56 and Sections 5-7 below.
} 
theories, the outcomes of our moral theories can influence the conclusions of our descriptive or conceptual theories. ${ }^{14}$

Unfortunately, the proponents of the normative critique are not entirely clear about what this more complex relation between moral and conceptual inquiries about the law consists in, or about the tension it creates for views that accept both LCA and the denial of law's authority. Consequently, the precise nature of the normative critique remains somewhat obscure. The following two sections spell out and discuss two possible interpretations of the normative critique, each inspired by certain remarks by Soper. The first follows up on the suggestion by the proponents of the critique that the damaging conflict obtains between (i) LCA and (ii) the denial by legal positivism that law is necessarily authoritative. The second interprets the conflict to be between (i) LCA and (ii) the (stronger) denial that there is a general duty to obey the law. ${ }^{15}$ In either guise, the normative critique holds that a theory of law that contains LCA is guilty of a conceptual incoherence of some sort. ${ }^{16}$ However, I will argue that each is to be rejected. Section 5 will then pick up on parts of the second interpretation and construct a more appealing reading of the normative critique.

\section{First Interpretation: A Clash within Positivism}

The first possible interpretation of the normative critique focuses on legal positivist theories in particular. On this reading the critique holds that positivist theories that endorse LCA suffer from a kind of internal contradiction. The contradiction is that such theories deny that law is essentially

\footnotetext{
${ }^{14}$ Soper is adamant about this point. See especially Soper, The Ethics of Deference (n 2) 17-20 and ch 3. Similarly Steven Smith writes: 'if law must possess or at least claim authority in order to count as "law," as so many theorists suppose, and if it also turns out that [legitimate] authority does not actually exist, then it might seem to follow that . . . law does not exist?' See Smith (n 3) 99, 130. See also, Bertea (n 3) 4, 254, 271-75.

${ }^{15}$ Some confusion here is understandable. The (stronger) denial of a duty to obey the law combined with the observation that some legal systems exist entails legal positivism. Moreover, many legal positivists who accept LCA - at least on some interpretation-also accept the denial of a duty to obey the law-at least on some interpretation. For examples, see Raz, The Authority of Law (n 1) and Green, The Authority of the State (n 1). ${ }^{16}$ See Soper, The Ethics of Deference (n 2) 1-20, 51-54; Soper, 'Legal Theory and the Claim of Authority' ( $n$ 2) 212; Smith (n 3) 99.
} 
authoritative, yet are committed by LCA to seeing law as necessarily claiming such authority. The normative critique may then be summed up as follows: any theory that sees law as necessarily making a claim that the theory itself holds to be unjustified is problematic. ${ }^{17}$

This version of the argument fails for two reasons. First, the critique rests on an implausible reading of LCA. We can distinguish between two claims law might make:

(1) Necessarily law claims authority

And:

(2) Law claims that necessarily it has authority

Now it is clear that positivism does not hold that law cannot be authoritative; it denies that law must be authoritative. Consequently, (1) is not a claim to something with which legal positivism has a gripe. If there is to be a conflict internal to legal positivist theory, law's claim must be read as (2). That is, LCA must see law as claiming that its requirements are necessarily obligatory.

But this is an implausible reading of LCA. Law clearly does not make a (complex) modal claim about the binding nature of legal requirements as such. One way in which this is clear is that legal systems typically attempt to back up their claims to authority with claims of justice, ${ }^{18}$ and such claims would be entirely irrelevant if the content of LCA was (2). Moreover, there is little reason to think that law makes claims about the authority of legal systems other than itself. That is, LCA only holds that a legal system necessarily claims that its subjects are obligated to obey its legal requirements. Hence (2) seems, at best, a far-fetched reading of LCA. Instead, we should read law's claim to authority as simply the claim that legal requirements pose content-independent obligations.

\footnotetext{
${ }^{17}$ See Soper, The Ethics of Deference (n 2) 51-52 and accompanying footnotes and 'Legal Theory and the Claim of Authority' (n 2) 212. See also Bertea (n 3) 4, 254, 271-75.

${ }^{18}$ These are just the assertions on which non-positivists rest much of their case. Robert Alexy notes the strange nature of a hypothetical constitution asserting that ' $X$ is a sovereign, federal, and unjust republic'. See Robert Alexy, The Argument from Injustice: A Reply to Legal Positivism (Stanley Paulson and Bonnie Litschewski Paulson trs, OUP 2002) 36. Soper himself also sees law's claim as one of justice. See Section 7 below.
} 
Second, even if LCA should be interpreted as (2), this would still not pose a conceptual problem for legal positivism. For while positivism must on this reading indeed see law as essentially making a claim that, by the lights of the theory, cannot be true, this is not an understanding of law that commits any contradiction. The reason is that there is a distinction between the justifiability of the content of a claim and the justifiability of making that claim. It can be perfectly justifiable for someone to claim that something is the case even if it is not. For example, I may be justified in claiming that I have magical powers, even though I do not have them, when this will deter a person who is about to wrongfully harm someone else. Similarly, a positivist theory can coherently regard as justified the making of a claim the contents of which it deems false. Consistency at most requires of a theory of law according to which law makes a claim to authority that it did not regard law's making that claim as unjustified.

There are many reasons for why a theory might see law as justified in making a claim to authority that is false. I will quickly mention just a few. First, there may be serious costs to a legal system explicitly incorporating a weaker claim to authority. Such a claim would require various exception clauses and qualifications to law's requirements. Not only should the law include clauses as: never drive through a red light, unless driving on is necessary to alleviate a life-threatening situation, unless stopping is more dangerous than driving on, unless the light is clearly broken, etc. It might also have to include myriad other clauses such as: unless officials made a clear mistake in placing a traffic light here, unless you can clearly see no traffic is coming, unless there is some other over-riding reason for you to take the risk involved in driving on, etc. This would make the law endlessly complicated and may obstruct, for example, the coordination of social interaction. Additionally, attenuating law's claim to authority may also suggest to subjects that the exceptions law has explicitly spelled out are all the exceptions it will recognize. But this may well be practically impossible. In that case it may be preferable 
to keep law's strong claim so that all reasonable subjects will know that some discretion can be called

for some of the time. ${ }^{19}$

These points raise a host of complicated issues, ${ }^{20}$ and I do not here mean to argue that the making of the strong claim to authority by law would be justified. What these considerations show, however, is that legal positivism may adduce from the function and purpose of law good reasons in favour of a claim the content of which it sees as unjustified. The first reading of the normative critique is therefore to be rejected.

\section{Second Interpretation: A 'Bad' Concept of Law}

On the second possible reading, the normative critique holds that LCA is to be rejected because of its content. The supposed conflict is here between law's claim to authority and the view that there is no general duty to obey the law. The denial of law's authority follows from the arguments of so-called philosophical anarchist authors. Philosophical anarchists object that there is no compelling justification for the view that law's requirements do in fact impose content-independent obligations on its subjects. ${ }^{21}$ This view is often understood as the strong thesis that the law imposes content-independent obligations on no subject. However, the success of philosophical anarchism and the purported force of the normative critique depend only on a claim that is significantly weaker (and more plausible) than this.

\footnotetext{
${ }^{19}$ See Greenawalt, Conflicts of Law and Morality (n 9) 6-21; Raz, The Authority of Law (n 1) ch 2; Gans (n 1) 28-29, 147-49. The latter consideration is more speculative since it depends, among other things, on facts about human psychology and the contents of particular systems of law. Note that, depending on the facts, the converse might also be true. That is, even if people are not obligated to obey all of law's requirements, it may be that law's making a particularly strong claim to authority leads to higher compliance by subjects with independent moral requirements than would occur in the absence of such a claim.

${ }^{20}$ Such as questions concerning the proper role and scope of consequentialist reasons, publicity requirements within legal and political philosophy, certain facts about the world, and so on. For a defence of a claim to authority by law in this spirit and a discussion of some of the further issues such a view raises, see Larry Alexander, 'Law and Exclusionary Reasons' (1990) 18 Philosophical Topics 5. See also Larry Alexander, 'Pursuing the Good--Indirectly' (1985) 95 Ethics 315.

${ }^{21}$ See among others Robert Paul Wolff, In Defense of Anarchism (Harper \& Row 1970); A John Simmons, Moral Principles and Political Obligations (Princeton University Press 1979); MBE Smith, 'Is There a Prima Facie Obligation to Obey the Law?' (1973) 82 Yale L 950; Joseph Raz, 'The Obligation to Obey the Law' in The Authority of Law (n 1); Green, The Authority of the State (n 1$)$ ch 8.
} 
For law to lack the authority it claims to possess it is sufficient if it fails to impose content-independent obligations on at least some subjects. We can thus define this view as follows.

Philosophical anarchism (PA): At least some people subject to the law are not obligated to obey its requirements when law holds them to be so obligated.

PA holds that what law claims is the case cannot be justified. It holds that law's attempt to impose moral obligations on its subjects may fail to bring them about. In other words, according to PA law cannot make good on its claim to authority.

The normative critique, on this reading, asserts that LCA becomes problematic if PA is true. Note that on the current reading the critique no longer strikes against legal positivism as such, but just against LCA. But again the conclusion that LCA is problematic is supposed to follow from the nature of, and standards of success for, conceptual analysis. In conceptual analysis we aim to specify a set of conditions for the application of a concept. One way in which we can evaluate various candidate understandings of a concept is by considering what existing entities fall under those understandings, and exclude candidates that fail to meet a sufficient number of actual cases or sufficiently central cases that we intuitively identify as falling under the concept. Another aim, Soper stresses, is to achieve logical coherence between the concepts that make up our overall framework of understanding. ${ }^{22}$ This is where the current reading of the normative critique finds its foothold: we are to reject or reformulate our understanding of concepts when (elements of) these are in tension or contradiction with (elements of) other concepts to which we give credence. LCA holds that law makes a claim that is denied by PA. This

\footnotetext{
22 '[T]o claim that a particular feature of an enterprise is essential to the concept means, for the purposes of this study, only that the feature is required in order to avoid inconsistency with other existing concepts or practices.' Soper, The Ethics of Deference (n 2) 30. Soper does not quite make good on this, as (clearly) he invokes a number of other arguments as well.
} 
leads to a gap between what law claims and what law is, and thus, assuming the truth of PA, LCA has to go. $^{23}$

The problem with this version of the critique is that it is unclear what is problematic about concepts that are, or contain elements that are, unjustifiable. Often it seems perfectly acceptable, and sometimes unavoidable, to adopt a conceptual understanding of a practice as one that fails to stand up to moral scrutiny. Indeed, it is not difficult to come up with cases where such conflicts occur in even starker form. Theft, rape and slavery are all unjust, even conceptually so, but this does not mean that we should redefine our understanding of those practices. On the contrary, where theft, rape or slavery exists we have reason to change those practices, not our understanding of them. And the very fact that we can understand these as unjust practices is a prerequisite for our judgment that they ought to be stopped.

But perhaps the problem is not due to the claim being morally unjustifiable, but simply to the claim being false? Unfortunately, on this reading the normative critique fares no better. For we are also familiar with concepts that involve the making of claims that are false. Consider, for example, scientific theories. Almost all rival scientific theories make claims about the world that are false. However, this provides us with no good reason to change our understanding of them. Nor need it be problematic if the combination of LCA and PA implies a view according to which law necessarily makes a claim that is false. Consider the concept of a liar. All liars, at least on some understandings, necessarily make claims that are false. ${ }^{24}$ But surely we are not then to conclude that we should revise our concept of a liar. It seems clear, then, that if these concepts are acceptable, Soper's view about conceptual analysis casts far too

\footnotetext{
${ }^{23}$ See Soper, The Ethics of Deference (n 2) 52. Leslie Green seems to adopt this reading of Soper's argument in his 'Review of Philip Soper, The Ethics of Deference: Learning From Law's Morals' (2003) 4 Notre Dame Philosophical Reviews 4, as does Himma (n 4). It must be mentioned here that Soper is playing somewhat fast and loose with the notion of a concept. Can LCA or PA be dubbed concepts? I presume that he has in mind that one is committed, if one accepts PA, to certain concepts (for example, autonomy) the normative implications of which rule out (some of) the implications of LCA. But see Section 6 below.

${ }^{24}$ See Thomas L Carson, 'The Definition of Lying' (2006) 40 Noûs 284. Section 6 below argues that the combination of LCA and PA regards law more like a mistaken scientific theory than a liar.
} 
wide the demand for consistency between concepts. Whatever kind of (in)consistency at stake in this case is neither here nor there for the question whether law makes certain claims.

\section{Third Interpretation: The Oddness Thesis}

The normative critique is often presented as identifying a conceptual incoherence faced by theories of law that incorporate LCA. We have seen that on either interpretation of that argument, the objection fails. However, we can construct a third and more compelling version of the argument. On this reading, the normative critique holds that the truth of PA means that a conceptual understanding of law that includes LCA is, although not incoherent, 'odd'. That is, a theory of law according to which law claims to impose content-independent obligations is an odd theory given the (assumed) fact that law fails to impose such obligations.

This third reading of the normative critique departs from a different claim made by Soper. This is the claim that it is a 'truism about human behaviour that conscientious people ... do not ... issue demands or take action that affects others, unless they implicitly believe that what they are doing ... is based on morally defensible (sincerely held) beliefs about what is permissible or right to do. ${ }^{25}$ At times Soper seems to think that this directly implies that we can reject LCA if PA is true. He argues we must distinguish between the claims of law (our topic) and the actual aims and motivations of those individuals who work within the legal system. Thus it might seem to follow from his statement that we simply must ascribe to law a claim made in good faith, something which might in turn rule out LCA if PA is true. However, quite apart from the fact that false (as well as morally unjustifiable) claims can be made sincerely too, such an argument would take the personification of the law involved in ascribing claims to it too far. We cannot readily extend an observation that may apply to actual persons to law personified. Thus, unless Soper's argument rests (as LCA emphatically does not) on the unattractive

\footnotetext{
${ }^{25}$ Soper, The Ethics of Deference (n 2) 58. See also Section 7.
} 
proposition that the grounds for ascribing claims to law are entirely independent of the content of the law, the structure of legal requirements, and the roles and functions of legal officials must enter into the question of whether or not LCA can be imputed to the law.

However, at other times, Soper suggests a more indirect, and I believe more interesting, version of this argument. This argument focuses on legal systems in particular and holds that it is difficult to understand both the prevalence and functioning of legal systems if indeed it is true both that law makes a claim to authority and that this claim is false. There are at least two reasons for why this might lead one to think LCA an odd theory. The first has to do with the fact that law is, as Soper stresses, a highly self-reflective institution. If it is true that, at least most of the time, people act sincerely, it is puzzling to ascribe to law a claim that is false. Such a self-reflective institution could hardly keep up making claims that are false. If both LCA and PA were true, would the news not have reached legal officials by now? Would people not have abandoned law at least somewhere, at least sometime? Oddness here results from the evidence provided by human history (given certain motivational assumptions) about the nature of law. $^{26}$

The second reason focuses on a different part of the nature of law. This has to do with the moral consequences of law's claim to authority being false. If LCA is false, it would seem that legal systems treat their subjects in ways that are morally problematic. For treating subjects as if they are subject to authority in the absence of a compelling justification fails to respect them as moral equals. It regards them as beings who are subject to one's will, beings with whom one stands in a relation that allows one to impose moral obligations. As Kant, among others, has famously pointed out, such a stance may well fail to take them sufficiently seriously as agents; it may express a kind of condescension. On the one

\footnotetext{
${ }^{26}$ 'The discrepancy arises because the typical attitude of the insider is that law obligates just in virtue of its existence. That belief . . . is the datum that conflicts with and is resistant to [PA].' Soper, 'Legal Theory and the Claim of Authority' (n 2) 213. See also, The Ethics of Deference (n 2) 78 or his argument that people would generally react differently to law's claims if law did not have authority around 13, and 'Law's Normative Claims' (n 2) 216.
} 
hand this is odd for reasons similar to the ones just given. If it is true, as Soper explicitly claims, that people are generally morally motivated, the prevalence of legal systems across different times and societies might be a surprise in light of the combination of LCA and PA. On the other hand it is odd in light of the observations, made time and again by both positivist and non-positivist legal thinkers, about the various connections between law and morality.

We can sum up the basic motivation for the argument, thus construed, as that it is strange to suggest-as the combination of LCA and PA might seem to suggest-that law is necessarily committed to things to which morally it cannot live up. Such a view might seem to imply that law is conceptually similar to a liar, and it is hard to deny that this suggestion is (at least) odd. Let us assume for now that these two sources indeed have the potential of rendering a proposed theory of law odd, and that oddness may count against a proposed theory of law. We can now formulate what we may label the oddness-thesis.

Oddness-thesis: A theory of law is prima facie implausible if it holds that law essentially claims something is the case that is unjustifiable.

The oddness-thesis provides the basis of a novel and interesting argument. And it is here that, in my view, much of the interest of the normative critique lies. Its upshot is explicitly not a knockdown argument against any theory of law. However, it might plausibly be said that if we have available two otherwise coherent and plausible theories of law, only one of which is not odd, that theory will be preferable. As such, reading the normative critique along the lines of the oddness-thesis provides it with force. For it does seem that a theory of law that regards law as essentially committed to something that is unjustifiable would present a stranger view than one according to which law is, or at least has the potential to be, justified.

The best interpretation of the normative critique therefore is that LCA is an odd view. This fits well with Soper's other arguments, for he claims to have an alternative theory of law's claims - what we 
may call: 'law's claim to justice' - that is not committed to any oddness at all. The remainder of this piece will evaluate this version of the normative critique. The next section inspects if, and if so in what sense, LCA is odd. Section 7 discusses Soper's preferred alternative to LCA and evaluates it in light of the oddness-thesis.

\section{Is Law's Claim to Authority Odd?}

Whether LCA violates the oddness-thesis depends on the precise conflict that obtains between LCA and PA. What is the precise objection posed by PA to law's pretensions of authority? Soper bases much of his argument about the tension between PA and LCA on the following observation: 'law and morality seem to confront each other according to these standard current views as distinct normative systems, resting on fundamental differences about the role of individual evaluation in determining what to do. ${ }^{27}$ Unfortunately, there are two clauses in this diagnosis and it remains unclear which Soper takes to be the heart of the matter: (A) that law presents itself as a distinct normative system, or (B) that law does not see individual evaluation as relevant for whether its requirements are binding. I will briefly discuss both these ways of reading LCA and ask to what kind of conflict with PA they might lead. I will argue that neither interpretation poses an attractive reading of LCA and point towards a third possible interpretation. This view not only poses a more attractive reading of LCA in its own right, but also avoids most of the force of the normative critique.

(A) According to the first of Soper's suggestions, when law claims authority it claims that its requirements are binding just in virtue of their legal nature. That is, law is said to claim that the obligations it imposes (legal obligations) that are on a par with, but different from, moral obligations. Just as we should, other things equal, comply with our moral obligations for the simple reason that they are moral obligations, the law sees its requirements as similarly binding for the simple reason that they

\footnotetext{
${ }^{27}$ See Soper, The Ethics of Deference (n 2) 12. Both suggestions are recurrent in the discussion on 9-13.
} 
are legal obligations. Thus Soper describes LCA as involving the claim that law constitutes a 'distinct normative system. ${ }^{28}$ And thus legal obligations can, in virtue of their nature as legal obligations, compete with moral obligations concerning what people ought to do-for example when the law requires something that is unjust.

The first way of reading LCA, then, is that part of law's claimed authority is that its (legal) obligations are what we might call 'primitive' obligations: their capacity to affect people's practical reasoning does not depend on some further, more fundamental, source such as an independent moral requirement. The theory that comes closest to such a view is probably the one originally defended by HLA Hart. Hart denied that legal obligation could be understood in terms of moral obligation, but saw both legal and moral obligations as derived from social rules spelling out requirements for persons. Hart held that those rules are what give obligations their binding nature. Since we might view morality and the law as distinct social practices in this way, we might see law and morality as distinct normative systems claiming to impose on persons in independent ways the same thing: genuine obligations. ${ }^{29}$

The normative critique on this reading depends on a version of PA that denies that law is obligatory in this sense. We can accept for now that a credible version of that argument can be made. Hart's particular understanding of obligation to which this reading appeals has been widely rejected. Surely there is a difference between acts being wrong and acts being contrary to social rules. Do we not sometimes think social rules are themselves wrong? To say that we should not break our promises because there is social pressure not to do so seems to get things the wrong way around: there is, one would hope, social pressure to keep one's promises because breaking promises is wrong. ${ }^{30}$ The core

\footnotetext{
${ }^{28}$ See Soper, The Ethics of Deference (n 2) 9-13. See also, 'law makes the claim that its norms obligate just in virtue of their existence' (11).

${ }^{29}$ See HLA Hart, The Concept of Law (2nd edn, Clarendon Press 1997) and 'Legal and Moral Obligations' in AI Melden (ed), Essays in Moral Philosophy (University of Washington Press 1958).

${ }^{30}$ See among others, Ronald Dworkin, 'The Model of Rules II', Taking Rights Seriously (Harvard University Press 1977) 52-53; Mark Platts, 'Philosophical Scepticism about Moral Obligation-I' (1993) 67 Proceedings of the Aristotelian Society, Supplementary Volumes 175-94. For an argument that Hart is even committed to rejecting
} 
claim underpinning the view of legal obligations as 'primitive' in the same way as moral obligations therefore is implausible. $^{31}$

However, this interpretation of LCA is to be rejected. For the present reading of LCA simply does not express a view that many of its supporters nowadays accept. Most, if not all, who defend LCA explicitly regard law's claim to authority as a moral claim. Joseph Raz, for example, is very clear: '[T]he law claims for itself moral force. No system is a system of law unless it includes a claim of legitimacy, of moral authority. That means that it claims that legal requirements are morally binding, that is that legal obligations are real (moral) obligations arising out of the law. ${ }^{32}$ Similarly, virtually all who attempt to give justifications of the authority of law attempt to construct moral justifications for the view: they argue that subjects are under a general moral duty to obey the law. ${ }^{33}$ Thus, if Soper is to make good on his claim to be criticizing the currently dominant view of LCA, the current interpretation is to be rejected.

(B) The second possible interpretation of the view focuses on the latter clause of Soper's diagnosis. The justificatory problem with law's claim here is that it considers its requirements to impose moral obligations on its subjects 'without any apparent concern for individual evaluation of the merits of

this conception of obligation for reasons of his own legal theory, see 'HLA Hart on Legal and Moral Obligation' (1974) 73 Michigan L Rev 443.

${ }^{31}$ Hart himself later abandoned the view See HLA Hart, 'Postscript', The Concept of Law (n 28) 256. In Essays on Bentham Hart follows Raz in trying to capture the normativity of law by means of 'detached judgments'. See HLA Hart, Essays on Bentham (OUP 1982) chs VI and X and Raz, The Authority of Law (n 1) chs 7-8. See for discussion Postema (n 1) and Lyons ( $n 1$ ). Chaim Gans even goes so far as to assert that 'no one seriously holds such a view of the value of law' (n 1) 27.

${ }^{32}$ See Joseph Raz, 'Hart on Moral Rights and Legal Duties' (1984) 4 OJLS 123, 131. See also Raz, 'Authority, Law, and Morality' ( $\mathrm{n} 1$ ) and The Authority of Law (n 1) chs 2, 7, 8. See also Gardner ( $\mathrm{n} 6)$. Another illustration of this state of affairs is the oft-heard lament that with the onset of modernity this traditional understanding of authority (Authority?) has all but disappeared from our world-view. See Smith (n 3) or Michael White, 'The Disappearance of Natural Authority and the Elusiveness of Non-natural Authority' in Patrick Brennen (ed), After Authority (Lexington Books Rowman and Littlefield 2007).

${ }^{33}$ See for arguments that the present issue is to be understood in terms of moral obligations Gans (n 1) 5-10; Simmons ( $\mathrm{n} 21$ ) chs 1 \& 2; and Ruth Higgins, The Moral Limits of Law: Obedience, Respect and Legitimacy (OUP 2004) 173-78. 
its prescriptions. ${ }^{, 34}$ On this reading, law claims that the mere fact that it requires something is sufficient for its subjects to know that they are morally required to perform the relevant action. The relevant version of PA then denies that this is the case. This reading is supported by the fact that Soper refers to Robert Paul Wolff's autonomy-based argument for philosophical anarchism. According to this argument treating the law as authoritative would involve an impermissible surrender of one's autonomy. To acknowledge law's authority, Wolff objected, is to surrender one's will by relying in advance on the evaluation of actions by others-and this is something no moral agent, responsible for her own actions, can do. ${ }^{35}$

What precisely is the problem here? Sometimes it is said that the key issue here is whether the force of the obligations imposed by law is supposed to be absolute. If so, Wolff's objection can be avoided by arguing that the obligations involved are of a weaker, prima facie, kind. However, this is not quite right. For to hold that certain obligations are absolutely binding is perfectly compatible with the autonomy of agents. It is simply to remark on the quality or strength of those particular obligations; it is to say that, when subjects correctly reason about the (moral) merits of law's requirements, they will come to the conclusion that obeying is always the right thing to do. No surrender of the will is involved here. Moreover, no claim to such absoluteness seems to be involved in LCA. Law's claim is not to moral infallibility. For example, various legal systems at times allow for so-called choice-of-evils defences, and there is no reason to think that this may threaten their status as systems of law.

A better way of putting the point, and one that probably better tracks what Soper has in mind, is to say that law claims that its requirements are peremptory. Requirements are peremptory when they are supposed to guide action while precluding the agent's independent deliberation on the merits of the action. Such a claim would be in tension with Wolff 's arguments. For in this case, accepting law's claim would require one to unreflectively submit to others' judgments about what to do. And this may be

\footnotetext{
${ }^{34}$ Soper, The Ethics of Deference (n 2) 9, see also 12.

${ }^{35}$ Wolff (n 21) 14.
} 
something no autonomous person can justifiably do. If we accept this second interpretation, then, Wolff's argument for PA means that LCA falls foul of the oddness-thesis. For law would not only be making a claim that cannot be true, it would also fail to take sufficiently serious the status of subjects as moral equals. It follows, then, that the normative critique provides reason against accepting the version of LCA that involves a claim to peremptoriness. (That is, if a non-odd theory is available as well.)

(C) The fact that the peremptory reading of LCA conflicts with Wolff's argument for anarchism means that it considers law as essentially committed to something that is unjustifiable. Hence, the normative critique of the peremptory reading of LCA puts pressure on the defender of such a view. There is, however, a serious problem with this interpretation of the normative critique. For the argument misconstrues both LCA and PA.

First, consider LCA. All who defend LCA think that there can be such a thing as legitimate authority. A theory that holds that law claims authority must presuppose a conception of authority. And virtually all who have responded to Wolff's objections argue that acknowledging authority need not involve a violation of the autonomy of the individual. This reflects the fact that, at least on these accounts, authoritative requirements are not seen as peremptory requirements, but simply as obligations. But being obligated does not require that one suspend one's deliberation or surrender one's will. Hence, a claim to authority will involve no such claim either. It is simply the claim that the outcome of subjects' correct deliberations will tell them that law's requirements pose content-independent moral obligations. Nor does the argument for LCA provided above push us towards the peremptory reading. Hence, we should instead interpret LCA as the claim that legal requirements pose, quite simply, contentindependent moral obligations. ${ }^{36}$

\footnotetext{
${ }^{36}$ This might involve a claim that subjects are to replace or exclude certain reasons by authoritative reasons. That is, instead of providing peremptory reasons, authority may be said to provide so-called pre-emptive reasons. See Raz, The Morality of Freedom (n 1) 57-62; Raz, The Authority of Law (n 1) ch 1; Gans (n 1) ch 1; Green, The Authority of the State (n 1) ch 2.
} 
Second, consider PA. Following the fact that few consider Wolff's objection to be insurmountable, the more popular anarchist view argues that the conditions for such authority to actually exist have not been met. Whereas the former kind of anarchism denies the very possibility of legitimate authority, the latter holds that legitimate authority is possible but simply does not exist. (For example, because law's subjects have not consented to its authority.) For this reason, the former (Wolff 's view) is often labelled a priori anarchism, the latter a posteriori anarchism. The two positions support the same conclusion: the denial of the obligation to obey the law in societies like ours. But their arguments and theoretical commitments are radically different. ${ }^{37}$

Thus, if the normative critique is to target the dominant understanding of the relation between law and authority, the current reading of LCA is to be preferred. Let us now adopt this understanding of LCA and see whether accepting its denial, a posteriori PA, leads to oddness. The normative critique, on the most attractive view of the relation between law and authority, of LCA would be that LCA holds that law necessarily claims a kind of authority that it does not possess (due to the assumed truth of $a$ posteriori PA), but that it could have under different factual conditions.

Is this odd? If it is, then it is surely odd in a less damaging sense than the arguments above seemed to suggest. On the present reading LCA does not identify law as conceptually similar to a liar. For contrary to the concept of a liar, a concept of law that includes LCA is, as such, neutral with respect to the truth of that claim. If the claim made by a liar turns out to be true, she ceases to be a liar. But if law's claim to authority were to become true, it would not cease to be law (at least, not because of anything in LCA). Therefore, if there is any oddness in LCA it is of a different, and I will argue decidedly less harmful, sort. We can capture this difference by formulating two versions of the oddness-thesis.

\footnotetext{
${ }^{37}$ The terms a priori and a posteriori anarchism are coined by A John Simmons in his 'Philosophical Anarchism' and John Sanders in Jan Narveson (eds), For and Against the State (Rowman \& Littlefield 1996). Soper's discussion departs from a reference to Wolff's a priori anarchism. Unfortunately, Soper does not distinguish between a priori and a posteriori anarchism. In his otherwise excellent discussion of law's claim to authority, Himma also makes the mistake of conflating the two, viewing anarchism as the thesis that 'the claim to legitimate authority is necessarily false' (n 4) (277).
} 
Weak oddness-thesis: A theory of law is prima facie implausible if it holds that law essentially claims something is the case that is, as a matter of moral principle, unjustifiable.

Strong oddness-thesis: A theory of law is prima facie implausible if it holds that law essentially claims something is the case that is, as a matter of fact or as a matter of moral principle, unjustified. $^{38}$

(The former is stronger than the latter because it excludes all and more that is excluded by the weak version.)

It is clear that the weak oddness-thesis can fully draw on both sources of oddness. A theory that conceives of law as making a claim that is false and that treats its subjects in ways that are morally problematic is odd indeed. However, LCA on its most plausible interpretation violates only the strong oddness-thesis. But it is not clear in what sense a theory that violates only the strong thesis is odd. The strong thesis cannot draw upon the second source of oddness identified in section 5 . That is, a theory (like LCA) that violates the strong thesis does not present a vision of law as necessarily committed to viewing its subjects as not moral equals. For we saw that it is possible for the conditions for a general moral duty to obey the law to be satisfied, and in that case law's claims will be true. Additionally, the first source of oddness applies only in an attenuated sense. For while sincere people may be assumed to be unlikely to construe and maintain a practice that is fundamentally unjustifiable, it is less strange to suppose they would construe and maintain a practice that could be justified, but happens not to be. One reason is that, while well-meaning people may disagree about the justifiability of both kinds of practices, they may in the latter case additionally disagree about whether the conditions for the justified existence have in fact been met (or even can be met in a world like ours). We are quite familiar with this kind of disagreement, and it is no strange thing to say that as a result certain unjust practices have been

\footnotetext{
${ }^{38}$ The phrase 'as a matter of fact' is, of course, a little unfortunate since the existence of a moral principle may be a fact. But I hope its intended meaning is clear. A clearer, but less elegant, way of formulating it would be to substitute 'a matter of non-moral-principle' for 'a matter of fact'.
} 
allowed to continue to exist. ${ }^{39}$ Thus law's claim to authority expresses nothing more than that law typically overestimates its own moral import. But if that is an odd thing to say, it is not odd in a very damaging sense. For we often come across such arrogance. (And, a cynic might add, we tend to do so in particular when dealing with those in positions of political power).

\section{Soper's Proposed Alternative: Law's Claim to Justice}

We can conclude that while the normative critique of LCA puts some pressure on the view, this is hardly insurmountable. However, to fully evaluate the upshot of the normative critique for the question of law's claims, we must also consider the alternative to LCA proposed by Soper. Should his preferred theory avoid all oddness, the normative critique would provide presumptive evidence for that view. In this section I will argue that, on close inspection, it turns out that this alternative to LCA violates the more damaging weak oddness-thesis.

According to Soper, law makes a claim that falls short of authority, what he calls law's claim to justice. Soper writes that we should understand legal requirements as presenting themselves in a dual form:

The only claim one can derive from the concept of law ... [is that] the only reasons law claims citizens have for following the law are content-dependent ones (obey the law because the content is just) or coercive ones (obey the law because we have the right to impose sanctions if you don't). ${ }^{40}$

Together this dual claim forms law's claim to justice (LCJ). The first part of law's claim is a claim to moral correctness, while the second part, Soper argues, follows from the claim that law's procedures for

\footnotetext{
${ }^{39}$ Without wishing to pronounce on the issue of its justification, consider as an example disagreement about the justifiability of prostitution. Part of the disagreement here concerns the supposed immorality of commodifying sexual intercourse. But part of the disagreement also concerns the question whether the relevant background conditions (of freedom, most importantly) are present.

${ }^{40}$ See Soper, The Ethics of Deference (n 2) 54, see also 57 and 'Law's Normative Claims' (n 2) 223. Robert Alexy (n 18) also argues that law necessarily claims to be morally correct.
} 
formulating and applying law are just. The most important upshot is that legal requirements are said not to present themselves as content-independent obligations, but as content-dependent ones.

In order to assess whether law's claim to justice avoids oddness we must ask whether LCJ is justifiable. It is worth noting here that this issue has wider relevance, for if LCJ is correct this might open up a justification for the workings and existence of a legal system that does not appeal to the notion of a general duty to obey the law (or the ability of law to impose content-independent obligations). That is, if all of law's requirements are either just or, failing that, the result of sincere attempts at arriving at justice, we might justify the workings of and existence of a legal system or state by appeal to law's justice alone. Soper's view here appeals to an argument that has become increasingly popular over the last decades. This is the argument that the right to rule of a state and the duties of subjects to obey the law are two separate matters. Call this the separation-thesis. The separation-thesis opposes what is the classical view on this question, according to which the right to rule and the obligation to obey the law are deeply connected, or even logical correlates. Call this the correlativity-thesis. ${ }^{41}$ Theories that accept the correlativity-thesis attempt to justify the right to rule of a state by establishing that its subjects are under a general duty to obey the law-or, for short, that subjects have political obligations.

The reading of LCA defended above appeals to the same idea the correlativity-thesis aims to express. Justifications for a state's right to rule that conform to the separation thesis are structurally similar to law's claim to justice. The central argument here is that we should conceive of the 'right to rule' not (i) as a Hohfeldian claim-right correlating to a duty to obey the law, or (ii) as a power, correlating to a liability, but (iii) as a liberty-right, correlating to the absence of a right on the part of

\footnotetext{
${ }^{41}$ See A John Simmons, 'Justification and Legitimacy' in Justification and Legitimacy (CUP 2001); Ronald Dworkin, Law's Empire (Harvard University Press 1986) 190. It is worth noting that Soper earlier endorsed the correlativitythesis, see 'Legal Theory and the Claim of Authority' (n 2) 220.
} 
law's subjects against being so governed. ${ }^{42}$ One might justify a liberty-right to rule without having to appeal to a general duty to obey the law by showing that the content of law is just, or at least a (reasonably successful) sincere attempt at arriving at justice. For in that case no one can complain about being wronged when they are subjected to such laws. ${ }^{43}$

We might evaluate the question of whether LCJ is odd, then, by asking whether we can justify a legal system's legitimacy or right to rule by reference to the just nature of its laws and its procedures. This is a deep and complex question, one that surely cannot be settled in the space of this discussion. However, there is at least one serious problem with Soper's appeal to the separation-thesis for the purpose of his argument. The problem is that, if the justification of the right to rule depends on the just content of law, we lose the ability to justify another crucial feature of all legal systems. This is what we may call their claim to uniqueness. Legal systems regard themselves as not just capable of formulating and enforcing rules for their societies; they see themselves as, within their own domain, the one supreme authority in their jurisdiction. Legal systems present themselves as the sole legitimate authority within their jurisdiction. ${ }^{44}$ If we reduce law's claim to one of merely interpreting, settling, and enforcing pre-existing moral requirements, we lose the ability to explain how this crucial feature of law may be justified. For the directives of other legal systems can equally accurately track justice (and may even do better). How can law be justified in preventing the application of such (just) laws within its jurisdiction if the basis of legal authority is the just content of legal requirements?

This means that $L C J$ is vulnerable to the full force of the normative critique. For given that law necessarily makes a claim to uniqueness in its own domain, and that such a claim cannot be justified by

\footnotetext{
${ }^{42}$ See for example Robert Ladenson, 'In Defense of a Hobbesian Conception of Law' (1980) 9 Philosophy and Public Affairs 134; Rolf Sartorius, 'Political Authority and Political Obligation' (1981) 67 Virginia L Rev 3; Greenawalt, Conflicts of Law and Morality ( $\mathrm{n}$ 9) ch 4; William Edmundson, Three Anarchical Fallacies (CUP 1998) pt 1.

43 ' [T] he law's minimal moral claim is that it is justified in imposing sanctions for breaking laws as long as the content and procedures are believed to be correct (regardless of whether they are correct in fact)', Soper, 'Law's Normative Claims' (n 2) 223. See also The Ethics of Deference (n 2) 71-74.

${ }^{44}$ What I here call 'uniqueness' is also often termed 'supremacy.' See for discussion and defence of law's claim to supremacy, Raz, The Authority of Law (n 1) 118-19 and Green, The Authority of the State (n 1) ch 3.
} 
appeal to LCJ, law necessarily makes a claim that is, in light of the theory, false. This means the view is open to the first source of oddness: given the highly self-reflective nature of legal systems and certain motivational assumptions about the people that populate them, puzzles arise about the prevalence of legal systems. The view is also open to the second kind of oddness: if LCJ were correct, how are legal officials supposed to be, and see themselves as, justified in enforcing the unique position of the system in which they perform their functions? How can they possibly both respect citizens as moral equals and prohibit them from doing what they sincerely regard as genuinely morally the right thing, just by claiming that, in their own eyes, they (the officials) are doing the morally right thing?

This is already sufficient to defeat LCJ, but there is a second problem as well. This problem becomes clear once we ask whether we can plausibly say that law's claim is to accurately track justice. For any realistically imaginable legal system will contain laws that simply cannot be reasonably described as the product of sincere attempts to establish justice. We know of many laws that aim, overtly or not, at other ends. This follows from two facts about legal systems. First, there is the simple observation that legal systems are the product of deeply fallible and sometimes weak-willed human beings. As a result, there will inevitably be laws that are the result of special interest lobbying, that attempt to prohibit morally innocent ways of life that certain groups deem offensive, that serve nonmoral goals such as increases in efficiency, that are adopted for prudential or (merely) aesthetic reasons, and so on. Some of these laws may well aim at legitimate ends and some may need to be part of any well functioning legal system. But in any case, it is clearly inaccurate to describe the law as unequivocally aiming at justice. LCJ, therefore, will struggle to explain how law can justifiably consider such laws as imposing obligations as well.

Again, this means that LCJ is seriously odd. For it shows that LCJ cannot accurately capture all instances in which law holds its subjects to be required to perform certain actions. Thus LCJ is committed to a claim which cannot be true, and consequently runs into the first source of oddness. And 
given that the claim to justice is false, it follows that, according to Soper's proposal, law must consider itself in a position to force upon its subjects even non-moral ends. Absent some further justification, one that would take us beyond the scope of LCJ, such a position is impossible defend. Note that LCA, in contrast, does not run into the same objections. For, first, law's claimed ability to impose obligations, and its concomitant claim of a duty to obey, are a straightforward way of claiming and justifying that its subjects owe it a form of special allegiance. Law claims that its subjects are obligated to follow its requirements in particular and may thus be justified in enforcing its unique position in the same way it can be justified in enforcing any other legal requirement. And second, the defender of LCA can point out that legal officials must implicitly claim to be authorized to apply all laws, even those the content of which is non-moral or even morally suspicious. Officials can do this in good faith precisely because law's claim is that, as legal officials, they have the ability to impose content-independent moral obligations. ${ }^{45}$

\section{Conclusion}

The normative critique of LCA has not yet received much attention. This is regrettable, as I have argued, since the critique presents an intriguing objection to the view that law claims authority. While some of the ways in which it is presented rest on mistakes, one way of interpreting the critique poses an objection to LCA that has potential force. However, this objection turned out to be not very damaging. By contrast, I have argued that by the same standard the alternative to LCA defended by Soper perform considerably worse. For it runs afoul of the normative critique in a more serious sense. As a result, the normative critique provides positive support for LCA, and Soper himself is positively committed to the view.

\footnotetext{
${ }^{45}$ The argument above relies on the assumption that we can meaningfully speak of justice in a way that is (partially) independent of the law. Not all may accept that this is correct. However, Soper clearly accepts something like it. Moreover, second, its denial renders LCJ tautologically true, and therefore uninteresting. I thank an anonymous reviewer for pressing me to clarify this point.
} 